\title{
Experimental Evaluations of CROPWAT8 Irrigation Scheduling for Hot Pepper and WUE Through on-Farm Participatory Approaches, Northwest Ethiopia
}

\author{
Temesgen Fentahun Adametie*, Demeke Tamene Mitku \\ Email address: \\ temesgenfentahun09@gmail.com (T. F. Adametie),demeketamene8@gmail.com (D. T. Mitku) \\ ${ }^{*}$ Corresponding author
}

Department of Irrigation and Drainage, Pawe Agricultural Research Center, Ethiopian Institute of Agricultural Research, Pawe, Ethiopia

To cite this article:

Temesgen Fentahun Adametie, Demeke Tamene Mitku. Experimental Evaluations of CROPWAT8 Irrigation Scheduling for Hot Pepper and WUE Through on-Farm Participatory Approaches, Northwest Ethiopia. American Journal of Agriculture and Forestry.

Vol. 9, No. 4, 2021, pp. 189-200. doi: 10.11648/j.ajaf.20210904.15

Received: April 20, 2021; Accepted: June 21, 2021; Published: July 6, 2021

\begin{abstract}
Irrigation scheduling is a critical management input to ensure adequate soil moisture for optimum plant growth, yield, quality, water use efficiency, and economic return. Besides farmer irrigation practice including irrigation scheduling in Northwest Ethiopia is cultural. The objective of this study was to evaluate CROPWAT irrigation scheduling for hot pepper and water use efficiency through on-farm participatory approaches Northwest Ethiopia. The experiment was conducted at two sites in Awi Zone, Dangela district (Ligaba) and Jawe district (Wobomariam), Northwest Ethiopia for two consecutive years 2017 and 2018. The experimental design was used a paired ' $t$ ' design it compares the effects of CROPWAT8 irrigation scheduling versus farmer's irrigation practice under both the furrow irrigation system. From January to May irrigation season gross irrigation depth for hot pepper considering field irrigation application efficiency of $60 \%$ was 466.4 and 720.2 for Ligaba and Wobomariam site respectively. The paired ' $t$ ' analysis revealed that water use efficiency and hot pepper fresh yield were significantly increased under the CROPWAT8 irrigation scheduling practice as compared with farmers irrigation practice. Hot pepper water use efficiency was improved by $43.7 \%$ and $9 \%$, and hot pepper fresh yield was improved by $12 \%$ and $31.4 \%$ for Ligaba (high land) and Wobomariam (low Land) areas of Northwest Ethiopia. In addition to this participant farmers and stakeholders also evaluate CROPWAT irrigation scheduling positively it could be used locality conditions. This shows the CROPWAT8 irrigation scheduling has increased significant benefits (proper water usage and hot pepper fresh yield increment). We conclude that the CROPWAT irrigation scheduling system is a promising technology to estimate crop water and irrigation water requirements with when and how much irrigate to corresponding growth stage. And also, that can improve hot pepper fresh yield of small-scale irrigation in Northwest Ethiopia.
\end{abstract}

Keywords: CROPWAT Irrigation Scheduling, Farmer's Irrigation Practice, Northwest Ethiopia

\section{Introduction}

Small-scale irrigation is recognized as a policy priority in Ethiopia for the reduction of poverty [1] and climate adaptation [2]. Irrigated agriculture is becoming increasingly important in meeting the demands of food security, employment, and poverty reduction [3]. Irrigation scheduling is a critical management input to ensure adequate soil moisture for optimum plant growth, yield, quality, water use efficiency, and economic return [4]. The irrigation schedule which determines the timing and amount of irrigation water is governed by many complex factors, but microclimate plays the most vital role [5-7]. Therefore, it is important to develop irrigation scheduling techniques under prevailing vital conditions to utilize scarce and expensive water efficiently and effectively for crop production. Irrigation scheduling is planning when and how much water to apply to maintain healthy plant growth during the growing season $[8,9]$. Proper irrigation scheduling is a means for optimizing agricultural production and conserving water [10]. The goal of irrigation scheduling is to control the water status of the crop to achieve a targeted level of agronomic performance. The 
performance level can vary from optimizing irrigation input to optimizing the output where crop yield is maximized [11]. Irrigation scheduling is the use of water management strategies to prevent over-application of water while minimizing yield loss due to water shortage or drought stress. The efficiency of water use in agriculture is low with poor management and improper designs of water application systems [12]. High water loss results in lesser yield and reduced irrigated areas that are linked to ineffective water use. But the improved irrigation practices lead to more uniform water distribution, minimize water application, irrigation costs, nutrient leaching, and result in the economic viability of irrigated agriculture [13, 14]. However, in Ethiopia traditionally anyone understood that irrigating more water for the crops means getting more yield. Although that is true for some water-loving crops, like rice, that is not good for most crops, where the root zone is found at a certain depth under the soil. The water below the root zone of the plant is not available. If it happened, causes the leaching of an essential nutrient, increasing in the groundwater table (cause water lodging), and increase in salt content over the land surface [15]. Several studies were carried out in the past on the development and evaluation of irrigation scheduling techniques under a wide range of irrigation systems and management, soil crop and climate conditions. Among those, FAO-CROPWAT (version 8.0) irrigation water management computer simulation model was selected because of previous tests and satisfactory performance in number of worldwide locations under varying climate circumstances [16].

Hot pepper is among the most susceptible horticultural plants to drought stress because of the wide range of transpiring leaf surface and high stomatal conductance [17] and having a shallow root system [18]. For high yields, and adequate water supply relatively moist soils are required during each growing season [13, 19]. Hot pepper cultivation is known in warm and semi-arid countries including Ethiopia. In Ethiopia hot pepper is a high-value cash crop that is used in many ways as well as food [20]. However, farmers still practice traditional irrigation in Northwest Ethiopia's high land and low land areas Such as Dangela and Jawe districts is low productivity. For such condition, well managed and scheduled irrigation practice with respective crop stage is very necessary. The irrigator needs knowledge of the efficient use of water resources through different crop management practices and irrigation scheduling techniques. These farmers traditional irrigation practice needs improved technology with a demonstration for farmer's participatory approach. So, the objectives of this study were (1) To determine hot pepper crop water, irrigation requirement and irrigation scheduling, (2) To evaluate the experimental effects of CROPWAT irrigation scheduling compared to farmer's practice on crop and water productivity in Northwest Ethiopia.

\section{Methodology}

\subsection{Study Area}

The field experiment was conducted at two sites in Awi Zone, Amhara region, Northwest Ethiopia. Ligaba Keble small scale irrigation scheme, Awi zone, high lands of Ethiopia, and Wobomariam Keble small scale irrigation scheme, Awi zone, law lands of Ethiopia (Figure 1). The area locates $2014 \mathrm{~m}$ and $1120 \mathrm{~m}$ above mean sea for Ligaba and Wobomariam irrigation scheme respectively. The areas where there is unlimited water resource through smallholder farmers (the communities) to maximize production and intensity by growing crops during dry seasons.

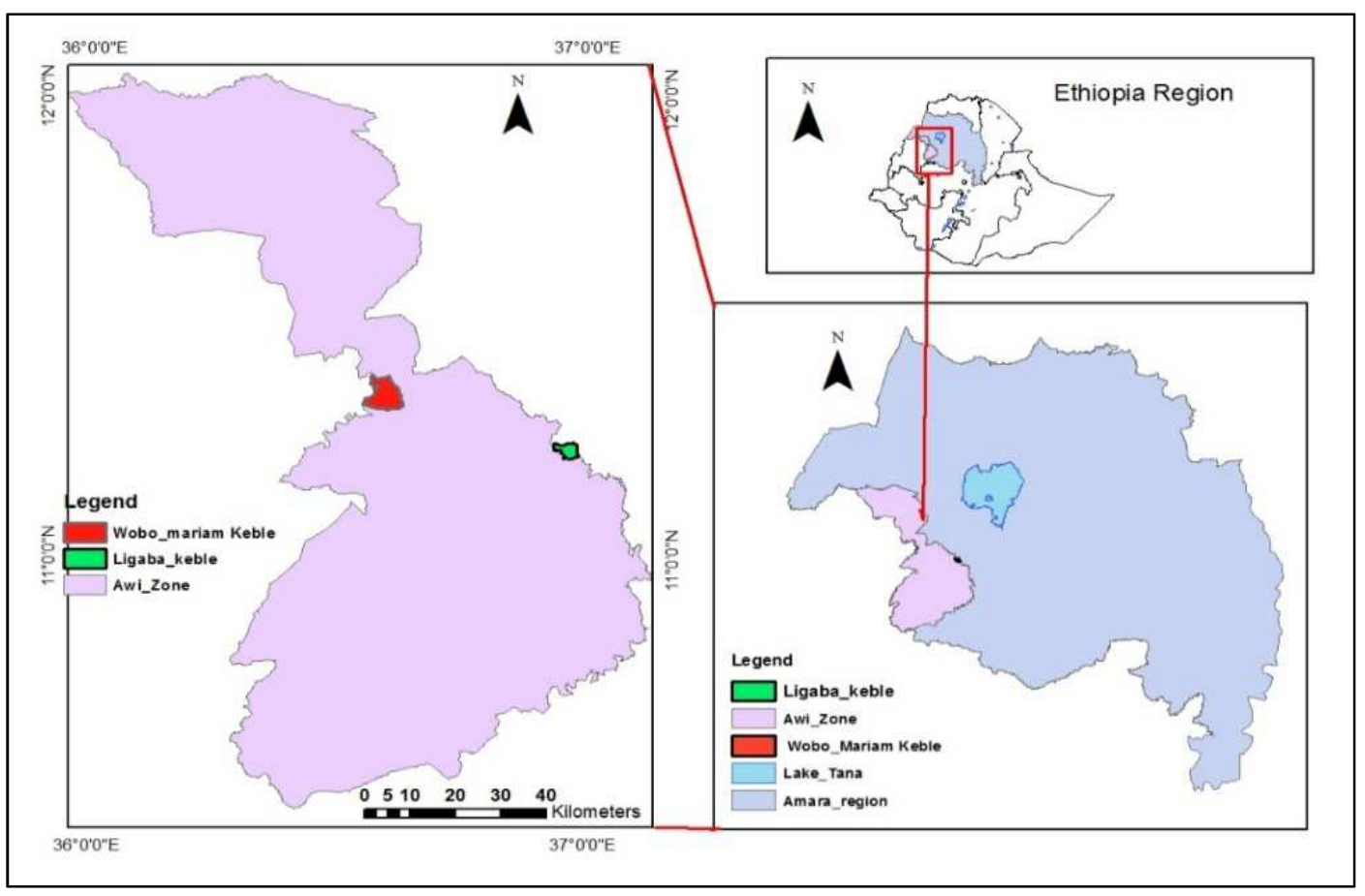

Figure 1. Location map of experimental sites in the northern part of Ethiopia. 


\subsection{Experimental Design and Setup}

A series of discussions were made with the local government, water users association leaders and agricultural development agents. The discussion aimed to locate the sites and select participant farmers. From discussions based on their interest, five farmers were selected to set the experiment and 50 farmers also to see each activity selected for each site. The experimental design was used a paired ' $t$ ' design it compares the effects of CROPWAT 8 irrigation scheduling versus farmer's irrigation practice under both the furrow irrigation system (Figure 2). The Paired ' $t$ ' test, a parametric procedure, is useful for testing whether the means of two groups are different, where the samples were drawn in pairs. The test is testing whether the mean of the differences of the pairs is different from zero. Paired ' $t$ ' is mathematically powerful to compare two paired measurements, which have intrinsic relationships, and do not require a large sample size which allows good control of individual differences [21]. De Winter [22] proved the applicability of paired t-test as low as two replicates. Several studies including. Yimam, Assefa [23], Belay, Assefa [24], and Assefa, Jha [25] have used paired-t design for similar purposes. In this experiment, irrigation scheduling with CROPWAT is the treatment and farmers' irrigation practice is the control (Figure 2). Experimental plots were assigned randomly for each management (i.e., Irrigation scheduling versus farmers watering practice).

The experimental setup was conducted in two consecutive years of 2017 and 2018 on a $200 \mathrm{~m}^{2}$ plot; where half of this size was assigned to irrigation scheduling $\left(100 \mathrm{~m}^{2}\right)$ and another half to farmers irrigation scheduling practice $(100$ $\mathrm{m}^{2}$ ) randomly.

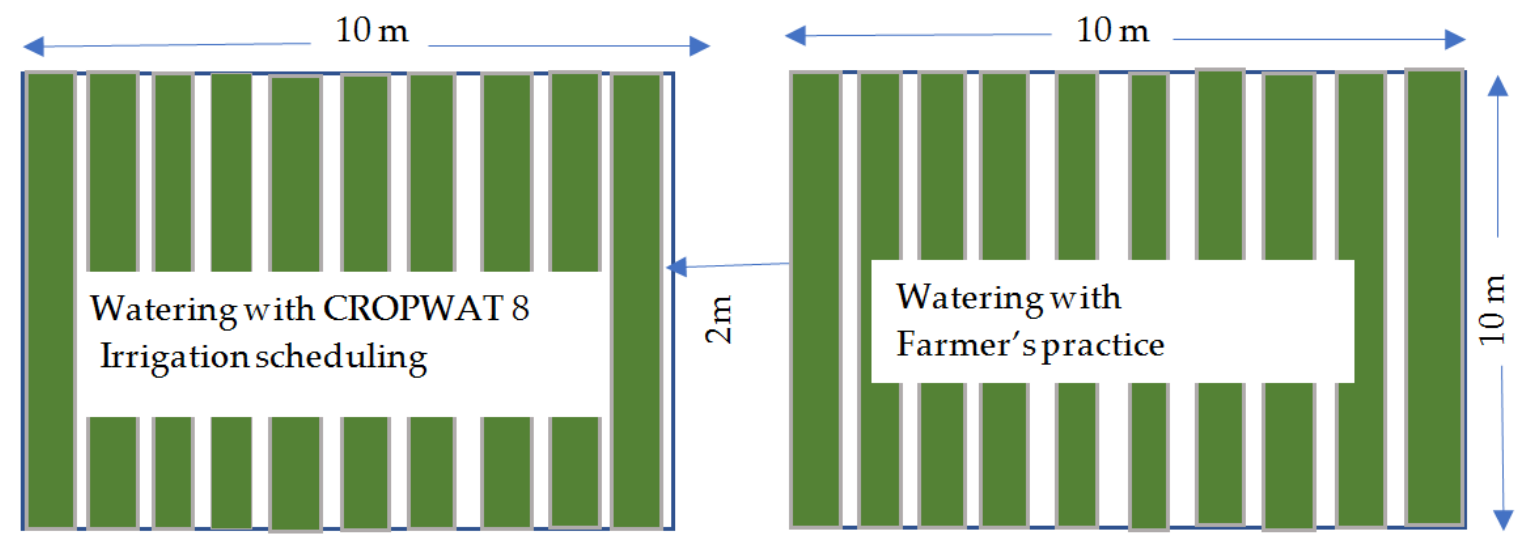

Figure 2. Experimental design Watering with irrigation scheduling versus watering with farmers practice both under furrow irrigation techniques.

\subsection{Climate Data}

Long term climatic data (maximum and minimum temperature, wind speed, sunshine hour, relative humidity) were collected from the nearby meteorological station, Dangela for the Ligaba site, and Pawe for Wobomariam site. The CROPWAT 8 model was used to estimate the reference evapotranspiration (ETo) using the Penman-Monteith method
[26] (Table 1) and (Table 2) respectively. Mean monthly ETo reaches its maximum value in April $(137.44 \mathrm{~mm} / \mathrm{month}$ in Dangela Ligaba site and $161 \mathrm{~mm} / \mathrm{month}$ in Jawe wobomariam site) and mean monthly minimum evapotranspiration reaches in July $(91.15 \mathrm{~mm} /$ month in Dangela Ligaba keble and $106.23 \mathrm{~mm} /$ month in Jawe Wobomariam) as shown in (Figure 3).

Table 1. Dangela Mean Monthly climatic data records Produced using 15 years (2001-2016).

\begin{tabular}{lllllll}
\hline Month & Min Temp & Max Temp & Humidity & Wind & Sun & ETo \\
\hline & ${ }^{\circ} \mathbf{C}$ & ${ }^{\circ} \mathbf{C}$ & $\mathbf{\%}$ & $\mathbf{~ m m} / \mathbf{d a y}$ & hours & mm/month \\
\hline January & 5.5 & 26.5 & 47 & 60 & 8.8 & 107.35 \\
February & 7.2 & 28.3 & 42 & 67 & 8.9 & 111.76 \\
March & 9.1 & 28.7 & 40 & 75 & 8 & 133.47 \\
April & 11 & 28.6 & 42 & 80 & 8.3 & 137.44 \\
May & 12.3 & 26.9 & 55 & 83 & 7.6 & 132.93 \\
June & 12.6 & 23.9 & 74 & 74 & 5.9 & 105.51 \\
July & 12.4 & 22.2 & 82 & 70 & 4 & 91.15 \\
August & 12.4 & 22.1 & 82 & 68 & 4.1 & 91.91 \\
September & 11.6 & 23.4 & 78 & 59 & 6 & 101.59 \\
October & 10.4 & 24.3 & 72 & 49 & 6.8 & 104.8 \\
November & 7.8 & 25.2 & 62 & 45 & 8.1 & 99.52 \\
December & 5.5 & 25.9 & 54 & 50 & 8.7 & 100.95 \\
Average & 9.8 & 25.5 & 61 & 65 & 7.1 & 1318.37 \\
\hline
\end{tabular}


Table 2. Pawe Mean Monthly climatic data records Produced using 29 years (1987-2016).

\begin{tabular}{|c|c|c|c|c|c|c|}
\hline Month & Min Temp & Max Temp & Humidity & Wind & Sun & ETo \\
\hline & ${ }^{\circ} \mathrm{C}$ & ${ }^{\circ} \mathrm{C}$ & $\%$ & $\mathrm{~km} / \mathrm{day}$ & hours & mm/month \\
\hline January & 11.8 & 34.2 & 38 & 40 & 9.7 & 116.4 \\
\hline February & 14.5 & 36.2 & 40 & 54 & 9.3 & 122.96 \\
\hline March & 17.9 & 37.6 & 45 & 65 & 8.7 & 154.51 \\
\hline April & 19.4 & 37.4 & 48 & 76 & 8.8 & 161.46 \\
\hline May & 19.4 & 34.9 & 58 & 79 & 8 & 155.65 \\
\hline June & 18.1 & 30.1 & 67 & 79 & 6.5 & 125.14 \\
\hline August & 17.6 & 27.7 & 71 & 51 & 4.8 & 106.57 \\
\hline September & 17.3 & 29.1 & 67 & 47 & 6.1 & 111.98 \\
\hline October & 16.8 & 30.5 & 63 & 30 & 7.3 & 115.69 \\
\hline November & 14.1 & 32.4 & 47 & 28 & 9.3 & 110.71 \\
\hline December & 12.2 & 33.7 & 40 & 41 & 9.8 & 114.54 \\
\hline Average & 16.4 & 32.6 & 55 & 54 & 7.7 & 1501.81 \\
\hline
\end{tabular}

\subsection{Rainfall Data}

The same to climate data for both site's long-term monthly rainfall data 16 years for Ligaba site and 29 years for Wobomariam site were collected. Effective rainfall (Pe) was determined using the United States Department of Agriculture Soil Conservation Service (USDA-SCS) method [27] and [16] as shown in (Equation 1). The effective rainfall was used later to determine water productivity for each crop under both irrigated and rainfed systems.

Mean monthly rainfall reaches its maximum value in August (390.5 mm in Dangela Ligaba site and $396.3 \mathrm{~mm}$ in Jawe Wobomariam site), and monthly effective rainfall starts April to November for Ligaba site and April to October for Wobomariam site (Figure 3).

$$
\left(\begin{array}{ll}
P e=0.8 P-25 & P>75 \mathrm{~mm} / \text { month } \\
P e=0.6 \mathrm{P}-10 & P<75 \mathrm{~mm} / \text { month }
\end{array}\right)
$$

Where $\mathrm{Pe}$ and $\mathrm{P}$ are effective rainfall and precipitation in $\mathrm{mm} / \mathrm{month}$, respectively.

Table 3. Effective rainfall and precipitation at both sites.

\begin{tabular}{lllll}
\hline & \multicolumn{2}{l}{ Dangela ligaba site } & \multicolumn{2}{l}{ Jawe Wobomariam site } \\
\cline { 2 - 5 } & Rain & Eff rain & Rain & Eff rain \\
\cline { 2 - 5 } & Mm & Mm & Mm & Mm \\
\hline January & 3.9 & 0 & 0.7 & 0 \\
February & 2.1 & 0 & 0.6 & 0 \\
March & 13.7 & 0 & 7.8 & 0 \\
April & 39 & 13.4 & 27.8 & 6.68 \\
May & 139.6 & 86.68 & 93.2 & 49.56 \\
June & 275.5 & 195.4 & 289.8 & 206.84 \\
July & 380.2 & 279.16 & 361.4 & 264.12 \\
August & 390.5 & 287.4 & 396.3 & 292.04 \\
September & 254.2 & 178.36 & 261.1 & 183.88 \\
October & 98.6 & 53.88 & 132.6 & 81.08 \\
November & 28.8 & 7.28 & 14.4 & 0 \\
December & 3.9 & 0 & 0.7 & 0 \\
\hline
\end{tabular}

\subsection{Soil Data}

In both experimental sites, randomly three sampling plots were selected. For each sampling plot three samples from 0 to $30 \mathrm{~cm}, 30$ to $60 \mathrm{~cm}$, and 60 to $90 \mathrm{~cm}$ total of 15 samples were taken. The samples were analyzed for different soil physical properties like field capacity, permanent wilting point and soil texture in the Pawe agricultural research soil laboratory.

\subsection{Crop Water Determination}

Crop water requirement refers to the amount of water that needs to be supplied, while crop evapotranspiration refers to the amount of water that is lost through evapotranspiration [16]. For the determination of crop water requirement, the effect of climate on crop water requirement, which is the reference crop evapotranspiration (ETo) and the effect of crop characteristics (Kc) are important [28]. Maximum effective root zone depth $(\mathrm{Rz})$ of hot pepper ranges between 0.5-1 $\mathrm{m}$ and has allowable soil water depletion fraction $(\mathrm{P})$ of 0.25 [29]. Hot Pepper average Kc would be taken after adjustments have been made for initial, mid and late season stage to be $0.6,1.05$ and 0.95 , respectively [16]

The long term and daily climate data such as maximum and minimum air temperature, relative humidity, wind speed, sunshine hours, and rainfall data of the study area were collected to determine reference evapotranspiration, crop data like crop coefficient, growing season and development stage, effective root depth, critical depletion factor of hot pepper and maximum infiltration rate and total available water of the soil was determined to calculate crop water requirement using CROPWAT model

$$
\mathrm{ETc}=\text { ETo } \times \mathrm{Kc}
$$

Where: ETc, ETo and Kc are crop evapotranspiration, reference evapotranspiration and crop coefficient respectively.

\subsection{Irrigation Water Requirements}

Water requirement of hot pepper was determined from climate data acquired from the regional metrological station by using CROPWAT 8.0 model. Gross irrigation depth was estimated considering field irrigation application efficiency of $60 \%$. Accordingly, net irrigation depths, gross irrigation depth and time of watering based on fixed irrigation intervals for each growth stages.

The total available water (TAW), stored in a unit volume of soil was determined by the expression 


$$
T A W=\frac{(\mathrm{FC}-\mathrm{PWP}) * \mathrm{BD} * \mathrm{Dr}}{100}
$$

The depth of irrigation supplied at any time can be obtained from the equation

$$
\operatorname{IRn}=\operatorname{ETc}(\mathrm{mm})-\operatorname{Peff}(\mathrm{mm})
$$

The gross irrigation requirement also obtained from the expression

$$
\operatorname{Irrg}=\frac{I R n}{E a}
$$

Where: Irrg, IRn and Ea are gross depth of water applied $(\mathrm{mm})$, Net irrigation depth and Water application efficiency of the furrows $(60 \%)$ respectively.

Water use efficiency

The water use efficiency was calculated by dividing harvested yield in $\mathrm{kg}$ per unit volume of water used in $\mathrm{mm}$ [13]. Water use efficiency (WUE): The crop water use efficiency is the yield harvested in $\mathrm{kg}$ per ha-mm of total water used.

$$
\mathrm{WUE}=\frac{Y\left(\frac{\mathrm{kg}}{\mathrm{ha}}\right)}{\operatorname{ETc}(\mathrm{mm})}
$$

Where: WUE, Y and Etc. are crop water uses efficiency ( $\mathrm{kg} / \mathrm{ha}-\mathrm{mm})$, Yield in $\mathrm{kg}$ ha-1 and Crop evapotranspiration $(\mathrm{mm})$ respectively.

\subsection{Farmers Perception About Experiment}

Field day was implemented with farmers and stakeholders' farmers were evaluating the experiment, farmers irrigation scheduling practice versus CROPWAT irrigation scheduling. The farmers compare the experiment for their own perception at different aspects i.e amounts of watering with crop growth stage, when and how much irrigate and obtained yield farmers irrigation practice compared to irrigation scheduling.

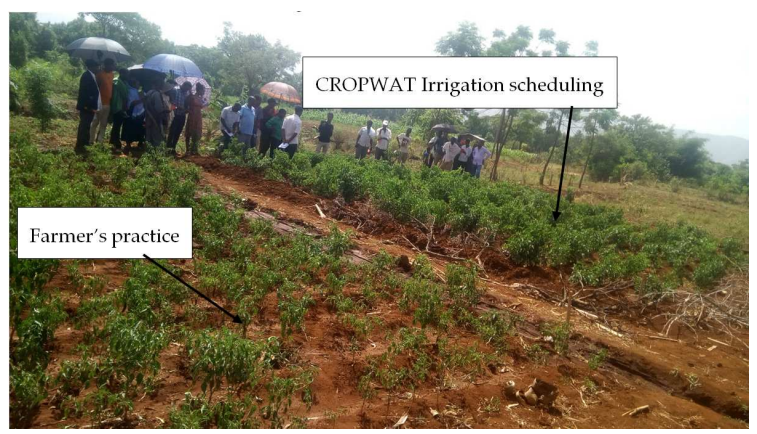

Figure 3. Field evaluations of farmers irrigation practice to CROPWAT irrigation scheduling with farmers, DA and researchers.

\subsection{Irrigation and Water Application System}

Furrow irrigation system was used for both irrigation scheduling versus farmers irrigation scheduling practice. In farmer's irrigation scheduling practice, the farmers use a traditional irrigation scheduling system underwater management to plant or transplant the hot pepper. Whereas in irrigation scheduling practice, we use the CROPWAT version 8 model to calculate irrigation water requirement and irrigation scheduling for hot pepper. According to Smith [8] crop growing stage with criterion classifications of hot pepper has four stages (Table 3). For each stage crop water requirement and irrigation scheduling were done. Parshall flume two-inch throat width was used to measuring irrigation water for both irrigation scheduling and farmers' irrigation scheduling practice. The water discharge measured with partial flume. For each irrigation, the amounts of watering date and amount of watering were recorded in both farmer's irrigation practice and technology irrigation scheduling practice.

Table 4. Category of crop growth stage classifications with each criterion.

\begin{tabular}{ll}
\hline Growing Stages & Descriptions \\
\hline Initial stage & Germination and early growth, little of the soil (less than 10\%) is covered with a crop. \\
Crop development & Up to when the crop achieves full ground cover \\
Mid-season & From full cover is achieved to maturity, when leaves start to discolors or fall off. Flowering and fruit set occur during this phase. \\
Late & From mid-season until harvest. \\
\hline
\end{tabular}

Source Smith [8] CROPWAT: A computer program for irrigation planning and management

\subsection{Crop Parameter Data}

A data collection system was developed for appropriate data analysis using paired ' $\mathrm{t}$ ' statistics. For both sites, Pepper (marko fan) variety was cultivated two consecutive years in the 2017 and 2018 dry season. For pepper production recommended spacing is $30 \mathrm{~cm}$ between plants and $70 \mathrm{~cm}$ between row was used [30, 31]. Farmers applied Urea (46: $\mathrm{N})$ fertilizer at a rate of $100 \mathrm{~kg}$ ha-1 for irrigated pepper. Crop characteristics such as plant height and crop yield were recorded. Plant height was monitored at harvesting. The measuring tape was used to measure plant height. The digital balance was used to determine the weight of the fresh yield of pepper.

\section{Result and Discussion}

\subsection{Reference Evapotranspiration, Effective Rainfall and Irrigation Seasons for Study Area}

The CROPWAT was used to inputs of long-term climate and rainfall monthly data the simulation were reference evapotranspiration and effective rainfall (Table 1, Table 2 and Table 3). Each month $\mathrm{ET}_{\mathrm{o}}$ values differences is reflect the variation in weather parameters in the study area. The low relative humidity, high temperatures, and high wind increased the evapotranspiration during the dry seasons [32, 33]. The distributions of each month reference evapotranspiration and effective rainfall was used to separate 
rainfall cropping season and irrigation cropping seasons. So, from the obtained result in both sites showed that rainfall cropping season partially high effective rainfall and low $\mathrm{ET}_{\mathrm{o}}$ were observed. and also, in irrigation season showed reverse of rainfall cropping season (Figure 3). From this obtained result we suggested that in both sites May end to October first is fully rain fall cropping season and October end to May first is irrigation cropping season. Based on this this experiment was starting from January to ending in May for both sites were implemented.

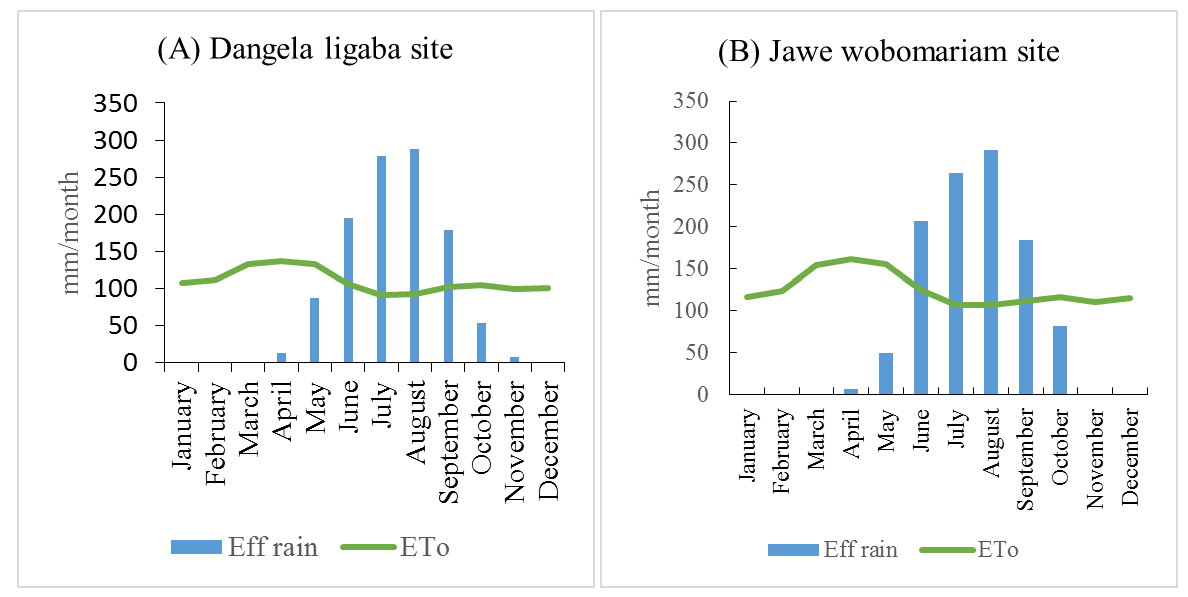

Figure 4. Monthly reference evapotranspiration and effective rainfall for (A) Dangela Ligaba and (B) Jawe Wobomariam.

\subsection{Soil Properties in Experimental Site}

At the surface average composition of sand, silt and clay percentages were $19 \%, 35.5 \%$ and $45.5 \%$, respectively for ligaba and $42 \%, 20 \%$ and $38 \%$ respectively for Wobomariam site (Table 4). Thus, according to the USDA soil textural classification the experimental site soil was classified as clay and clay loam for ligaba site and
Wobomariam experimental site respectively. From 0 to 90 $\mathrm{cm}$ soil depth water holding capacity of Ligaba soil experimental area showed between 0.13 to $0.15 \mathrm{~cm} / \mathrm{cm}$ whereas in wobomariam site water holding capacity is 0.12 $\mathrm{cm} / \mathrm{cm}$ of soil with depth is similar. And also, the average soil bulk density $\left(1.28 \mathrm{~g} / \mathrm{cm}^{3}\right)$ is below the critical threshold level $\left(1.4 \mathrm{~g} / \mathrm{cm}^{3}\right)$ and was suitable for crop root growth [34].

Table 5. Soil physical properties and water holding capacity Ligaba and Wobomariam site.

\begin{tabular}{|c|c|c|c|c|c|c|c|c|c|}
\hline \multicolumn{10}{|l|}{ Ligaba site } \\
\hline soil depth & & $\begin{array}{l}\text { Texture } \\
\% \text { sand }\end{array}$ & $\%$ silt & $\%$ clay & Soil class & $\begin{array}{l}\mathrm{BD} \\
\mathrm{gm} / \mathrm{cm}^{3}\end{array}$ & $\begin{array}{l}\mathrm{Fc} \\
\%\end{array}$ & $\begin{array}{l}\text { Pwp } \\
\%\end{array}$ & $\begin{array}{l}\text { Available water } \\
\mathrm{cm} / \mathrm{cm}\end{array}$ \\
\hline $0-30$ & Mean & 19 & 35.5 & 45.5 & Clay & 1.2 & 38.1 & 23.2 & 0.15 \\
\hline $30-60$ & Mean & 19.5 & 18.5 & 62 & Clay & 1.23 & 40.7 & 27.5 & 0.13 \\
\hline $60-90$ & Mean & 13 & 20 & 67 & Clay & 1.21 & 41.1 & 27.4 & 0.14 \\
\hline \multicolumn{10}{|c|}{ Wobomariam site } \\
\hline Soil depth & & $\begin{array}{l}\text { Texture } \\
\% \text { sand }\end{array}$ & $\%$ silt & $\%$ clay & Soil class & $\begin{array}{l}\mathrm{Bd} \\
\mathrm{gm} / \mathrm{cm}^{3}\end{array}$ & $\begin{array}{l}\mathrm{Fc} \\
\%\end{array}$ & $\begin{array}{l}\text { Pwp } \\
\%\end{array}$ & $\begin{array}{l}\text { Available water } \\
\mathrm{cm} / \mathrm{cm}\end{array}$ \\
\hline $0-30$ & Mean & 42 & 20 & 38 & Clay Loam & 1.16 & 35.8 & 23.6 & 0.12 \\
\hline $30-60$ & Mean & 38 & 24 & 38 & Clay loam & 1.14 & 35.8 & 23.6 & 0.12 \\
\hline $60-90$ & Mean & 32 & 34 & 44 & clay & 1.16 & 26.8 & 17 & 0.12 \\
\hline
\end{tabular}

Note: Bd, Fc and Pwp are bulk density field capacity and permanent wilting point respectively

\subsection{Crop Water Requirement, Irrigation Water Requirement and Irrigation Scheduling for Hot Pepper}

Crop water requirements (CWR) encompass the total amount of water used in evapotranspiration [35]. Water requirement of hot pepper was determined from climate data acquired from the regional metrological station Dangela and Pawe by using CROPWAT 8.0 model (equation 2). The ETc values were observed to be low at initial stage and high at mid stage that showed Kc value is increase with growth stages and back to at late stage. The CWR for hot pepper was higher during the mid and late season growth stages and lower during the initial and developmental stages. Studies the
Kc varied little, it was not constant in any growth stage; this also expresses the seasonal crop water needs $[32,36]$. The seasonal water requirements of hot pepper for each study area shows $462.7 \mathrm{~mm}$ and 532.2 for Dangela ligaba and Jawe Wobomariam site respectively. Effective rainfall is the part of rainfall which is effectively used by the crop after losses by surface runoff and deep filtration; it is used to evaluate the CWR [32]. The observed effective rainfall was $70.2 \mathrm{~mm}$ and $90.2 \mathrm{~mm}$ for ligaba site and wobomariam site respectively (equation. 1). Based on this obtained irrigation water requirement of this cropping seasons of hot pepper shows 390.7 and 437.7 for Ligaba and Wobomariam site respectively (equation 4) (Tables 5 and 6). 
Table 6. Dangela Ligaba site hot pepper growth stage crop coefficient (Kc), crop evapotranspiration (Etc.). Effective rainfall (Effr rain) and irrigation water requirement (Irr. Req.).

\begin{tabular}{|c|c|c|c|c|c|c|c|}
\hline Month & Decade & Stage & Ke & ETc & Etc. & Eff rain & Irr. Req. \\
\hline & & & coeff & $\mathrm{mm} / \mathrm{day}$ & $\mathrm{mm} / \mathrm{dec}$ & $\mathrm{mm} / \mathrm{dec}$ & $\mathrm{mm} / \mathrm{dec}$ \\
\hline Jan & 2 & Init & 0.6 & 2.08 & 4.2 & 0 & 4.2 \\
\hline Jan & 3 & Init & 0.6 & 2.19 & 24.1 & 0 & 24.1 \\
\hline $\mathrm{Feb}$ & 1 & Init & 0.6 & 2.29 & 22.9 & 0 & 22.9 \\
\hline Feb & 2 & Deve & 0.61 & 2.43 & 24.3 & 0 & 24.3 \\
\hline Feb & 3 & Deve & 0.7 & 2.86 & 22.9 & 0 & 22.9 \\
\hline Mar & 1 & Deve & 0.81 & 3.42 & 34.2 & 0 & 34.2 \\
\hline Mar & 2 & Deve & 0.94 & 4.06 & 40.6 & 0 & 40.6 \\
\hline Mar & 3 & Mid & 1.05 & 4.59 & 50.5 & 0.1 & 50.4 \\
\hline Apr & 1 & Mid & 1.05 & 4.72 & 47.2 & 1.1 & 46.1 \\
\hline Apr & 2 & Mid & 1.05 & 4.82 & 48.2 & 1.6 & 46.6 \\
\hline Apr & 3 & Mid & 1.05 & 4.71 & 47.1 & 10.8 & 36.3 \\
\hline May & 1 & Late & 1.03 & 4.51 & 45.1 & 19.9 & 25.2 \\
\hline May & 2 & Late & 0.95 & 4.06 & 40.6 & 27.6 & 13 \\
\hline May & 3 & Late & 0.89 & 3.6 & 10.8 & 11 & 0 \\
\hline Total & & & & & 462.7 & 72.2 & 390.7 \\
\hline
\end{tabular}

Table 7. Jawe wobomariam site hot pepper growth stage crop coefficient (Kc), crop evapotranspiration (Etc.). Effective rainfall (Effr rain) and irrigation water requirement (Irr. Req.)

\begin{tabular}{llllllll}
\hline Month & Decade & Stage & Kc & ETc. & ETc & Eff rain & Irr. Req. \\
\hline & & & coeff & mm/day & mm/dec & mm/dec & mm/dec \\
\hline Jan & 2 & Init & 0.6 & 2.25 & 4.5 & 0 & 4.5 \\
Jan & 3 & Init & 0.6 & 2.38 & 26.2 & 0.2 & 26 \\
Feb & 1 & Init & 0.6 & 2.51 & 25.1 & 0.1 & 25 \\
Feb & 2 & Deve & 0.61 & 2.67 & 26.7 & 0 & 26.7 \\
Feb & 3 & Deve & 0.7 & 3.19 & 25.5 & 0.6 & 24.9 \\
Mar & 1 & Deve & 0.81 & 3.88 & 38.8 & 1.4 & 37.4 \\
Mar & 2 & Deve & 0.94 & 4.68 & 46.8 & 2.1 & 44.7 \\
Mar & 3 & Mid & 1.04 & 5.32 & 58.5 & 4.3 & 54.2 \\
Apr & 1 & Mid & 1.05 & 5.49 & 54.9 & 5.7 & 49.2 \\
Apr & 2 & Mid & 1.05 & 5.63 & 56.3 & 7.3 & 49 \\
Apr & 3 & Mid & 1.05 & 5.51 & 55.1 & 13.7 & 41.4 \\
May & 1 & Late & 1.02 & 5.26 & 52.6 & 19.9 & 32.7 \\
May & 2 & Late & 0.95 & 4.75 & 47.5 & 25.4 & 22 \\
May & 3 & Late & 0.89 & 4.23 & 12.7 & 9.3 & 0 \\
Total & & & & & 531.2 & 90.2 & 437.7 \\
\hline
\end{tabular}

Note, Kc, ETc, Eff rain and Irr. Req. are crop coefficient, crop evapotranspiration. Effective rainfall and irrigation requirements respectively.

Once the crop water and irrigation requirements have been calculated, the next step is the preparation of field irrigation schedules [35]. Gross irrigation depth was estimated considering field irrigation application efficiency of $60 \%$ were 466.4 and 720.2 for Ligaba and Wobomariam site respectively. As Shown (Table 7), for both sites at initial stage irrigation interval was short with little amount of irrigation water was applied. The rest stage development, mid and late stage were long irrigation interval with high amounts of water was observed. For Ligaba site the observed irrigation interval was $(4,5,5,6,6),(7,7,8,8),(8,9,9,9,9)$ and $(0)$ with respective gross irrigation water requirements for initial, development, mid and late season stage respectively. Similarly, for Wobomariam site the irrigation interval was $(4,4,5,5,5),(6,6,6,7,7),(7,7,7,7,7,8)$ and (12) with respective gross irrigation water requirements for initial, development, mid and late season stage respectively. In other words, 5, 4, 5 and 0 times have been irrigated for initial, development, mid and late season stage respectively for Ligaba site and 5, 5, 6 and 1 times were irrigated for initial, development, mid and late season stage respectively for Wobomariam site. In this study similar crops but different gross irrigation water requirement, irrigation interval and irrigation frequency were observed. The difference might be different agroclimatic condition and different soil type. Agroclimatic conditions of Ligaba site is located high land area, relatively low temperature, minimum sunshine hour, high humidity and better effective rainfall was showed. Whereas in wobomariam located in low land parts, high temperature area, high sunshine hour, low humidity and low effective rainfall was showed. In addition to this soil class of ligaba was heavy clay and wobomariam was clay loam. Those reason is coming different gross water requirements. Studies for similar crop has at different climate condition and soil type different water requirement and gross irrigation water requirement [13, 14], Allen, Pereira [16], [29, 32]. 
Table 8. Hot pepper crop irrigation scheduling under CROPWAT system at Ligaba and Wobomariam site.

\begin{tabular}{llllllllll}
\hline Ligaba & & & & & Wobomariam & & & \\
\hline Date & Day & Stage & Net Irr & Gr. Irr & Date & Day & Stage & Net Irr & Gr. Irr \\
\hline & & & Mm & mm & & & & Mm & Mm \\
\hline 22-Jan & 4 & Init & 8.5 & 12.2 & 22-Jan & 4 & Init & 9.3 & 15.4 \\
26-Jan & 8 & Init & 8.8 & 12.5 & 26-Jan & 8 & Init & 9.5 & 15.9 \\
31-Jan & 13 & Init & 10.9 & 15.6 & 30-Jan & 12 & Init & 9.5 & 15.9 \\
05-Feb & 18 & Init & 11.2 & 16 & 04-Feb & 17 & Init & 12.4 & 20.6 \\
11-Feb & 24 & Init & 13.7 & 19.5 & 09-Feb & 22 & Init & 12.5 & 20.8 \\
17-Feb & 30 & Init & 14.5 & 20.7 & 14-Feb & 27 & Init & 13.2 & 22 \\
24-Feb & 37 & Dev & 17.9 & 25.6 & 20-Feb & 33 & Dev & 16 & 26.7 \\
03-Mar & 44 & Dev & 19.5 & 27.8 & 26-Feb & 39 & Dev & 18.8 & 31.4 \\
11-Mar & 52 & Dev & 26.5 & 37.9 & 04-Mar & 45 & Dev & 21.2 & 35.3 \\
19-Mar & 60 & Dev & 28.5 & 40.7 & 11-Mar & 52 & Dev & 27.2 & 45.4 \\
28-Mar & 69 & Mid & 33.8 & 48.3 & 18-Mar & 59 & Dev & 30.7 & 51.1 \\
05-Apr & 77 & Mid & 33.5 & 47.8 & 25-Mar & 66 & Mid & 33.7 & 56.2 \\
14-Apr & 86 & Mid & 34.2 & 48.9 & 01-Apr & 73 & Mid & 35.2 & 58.6 \\
22-Apr & 94 & Mid & 33.6 & 48 & 08-Apr & 80 & Mid & 32.8 & 54.7 \\
01-May & 103 & Mid & 31.3 & 44.7 & 15-Apr & 87 & Mid & 35.6 & 59.3 \\
23-May & End & End & 0 & 0 & 22-Apr & 94 & Mid & 35.6 & 59.3 \\
Total & & & 326.4 & 466.4 & 30-Apr & 102 & Mid & 36.5 & 60.8 \\
& & & & & 12-May & 114 & End & 42.5 & 70.8 \\
& & & & & & & 432.2 & 720.2 \\
\hline
\end{tabular}

Not, Net Irr and Gr. Irr are net irrigation and gross irrigation respectively.

Table 9. Effects of farmers irrigation scheduling practice and CROPWAT irrigation scheduling under each stage of applied water.

\begin{tabular}{llllllll}
\hline & Ligaba site & & & \multicolumn{3}{c}{ Wobomariam site } \\
\hline Stage & $\begin{array}{l}\text { 2017 Farmers } \\
\text { irrigation }\end{array}$ & $\begin{array}{l}\text { 2018 Farmers } \\
\text { irrigation }\end{array}$ & $\begin{array}{l}\text { Irrigation } \\
\text { scheduling }\end{array}$ & Stage & $\begin{array}{l}\text { 2017 Farmers } \\
\text { practice }\end{array}$ & $\begin{array}{l}\text { 2018 Farmers } \\
\text { practice }\end{array}$ & $\begin{array}{l}\text { Irrigation } \\
\text { scheduling }\end{array}$ \\
\hline Init & 30 & 32 & 12.2 & Init & 29.0 & 31.4 & 15.4 \\
Init & 31 & 40 & 12.5 & Init & 40.0 & 41.9 & 15.9 \\
Init & 25 & 42 & 15.6 & Init & 38.0 & 36.4 & 15.9 \\
Init & 33.2 & 40 & 16 & Init & 50.0 & 24.7 & 20.6 \\
Init & 25 & 48 & 19.5 & Init & 58.0 & 18.7 & 20.8 \\
Init & 30 & 45.5 & 20.7 & Init & 45.5 & 16.8 & 22.0 \\
Dev & 37.2 & 46 & 25.6 & Dev & 52.1 & 20.9 & 26.7 \\
Dev & 35.9 & 42.5 & 27.8 & Dev & 50.5 & 40.4 & 31.4 \\
Dev & 32 & 46.2 & 37.9 & Dev & 55.0 & 34.1 & 35.3 \\
Dev & 43 & 45 & 40.7 & Dev & 20.5 & 27.7 & 45.4 \\
Mid & 35 & 47 & 48.3 & Dev & 21.0 & 17.8 & 51.1 \\
Mid & 38 & 35 & 47.8 & Mid & 19.0 & 36.4 & 56.2 \\
Mid & 42.3 & 45 & 48.9 & Mid & 20.0 & 36.1 & 58.6 \\
Mid & 30 & 47 & 48 & Mid & 26.2 & 29.1 & 54.7 \\
Mid & 36 & 40.8 & 44.7 & Mid & 24.4 & 29.0 & 59.3 \\
Total & 503.6 & 642 & 466.2 & Mid & 22.7 & 29.0 & 5.3 \\
& & & & Mid & 21.0 & 28.9 & 60.8 \\
& & & & End & 19.2 & 28.9 & 70.8 \\
\hline
\end{tabular}

\subsection{Effects of Irrigation Scheduling Versus Farmers Irrigation Practice for Each Growth Stage}

In these two consecutive irrigation seasons study, each applied water was recorded in both farmers irrigation scheduling practice and CROPWAT irrigation scheduling practices. As shown Table 8, For both sites CROPWAT irrigation scheduling crop water requirement was similar in 2017 and 2018 because of similar transplanting date of each site. Whereas in farmers irrigation scheduling practice the applied water were deafferents in 2017 and 2018. For both study site farmers irrigation practice was not consider irrigation crop water requirement and their corresponding stage. As shown table 8 and figure 4, CROPWAT irrigation scheduling was considering soil water holding capacity, growth stage and hot pepper crop water requirements. Whereas, Farmers given water to crops only accomplishment of water it also almost similar amount of water from initial stage to late stage. Farmers was applied minimum and maximum irrigation water respectively were $25 \mathrm{~mm}$ at initial stage and $43 \mathrm{~mm}$ at development stage for 2017 and $32 \mathrm{~mm}$ at initial stage and $47 \mathrm{~mm}$ at mid stage for 2018 under Ligaba conditions. For wobomariam minimum and maximum water applied respectively $19 \mathrm{~mm}$ at mid stage and $58 \mathrm{~mm}$ at initial stage for 2017 and also 2018, $17.8 \mathrm{~mm}$ and $41.9 \mathrm{~mm}$ at initial stage were applied. Those applied water tells us farmers not 

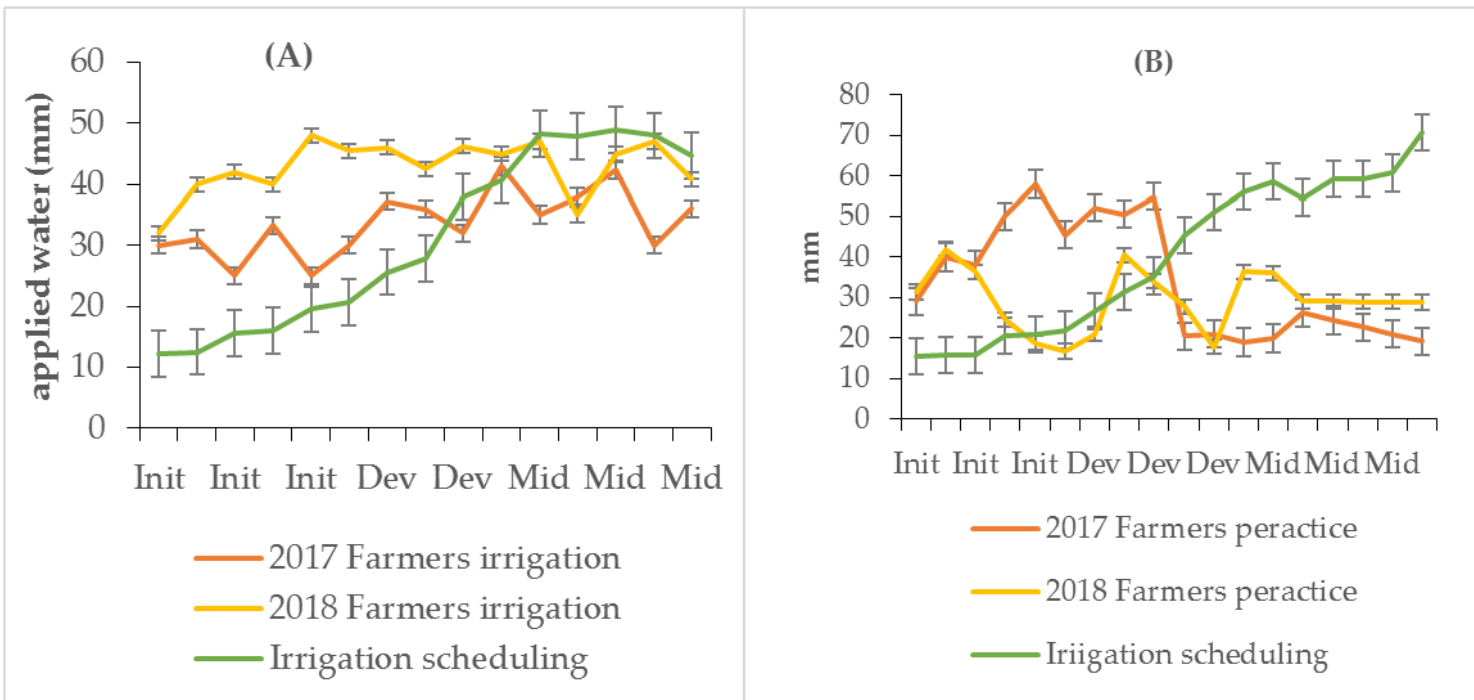

Figure 5. Effects of farmers irrigation scheduling practice and CROPWAT irrigation scheduling under each stage of applied water under 2017 and 2018 (A) Ligaba and (B) Wobomariam.

\subsection{Effects of Applied Irrigation Water Between Farmers Versus CROPWAT Irrigation Scheduling}

The mean total applied water to hot pepper were CROPWAT irrigation practice was lower than farmers irrigation practice at Ligaba site. Whereas in Wobomariam site CROPWAT irrigation scheduling was more than farmers irrigation practice (Figure 5) (Table 9). In the case of Ligaba the total applied water was 503.6, 642 and $466.2 \mathrm{~mm}$ for 2017 farmers irrigation practice, 2018 farmers irrigation practice and CROPWAT irrigation scheduling respectively. Whereas in the case of wobomariam site 612,528 and 720.2 $\mathrm{mm}$ for 2017 farmers irrigation practice, 2018 farmers irrigation practice and CROPWAT irrigation scheduling respectively.

The mean water uses of 2017 and 2018 farmers practice were used additional, respectively, by $8 \%$ and $37.7 \%$, when compared to CROPWAT irrigation scheduling at ligaba site. Whereas in Wobomariam site farmers irrigation practice 2017 and 2018 respectively withhold $17.6 \%$ and $36.4 \%$ when compared to CROPWAT irrigation. This study shown that farmers for different location have different indigenous knowledge. This study agrees with studies for farmer-tofarmer irrigation trend is not similar [24].

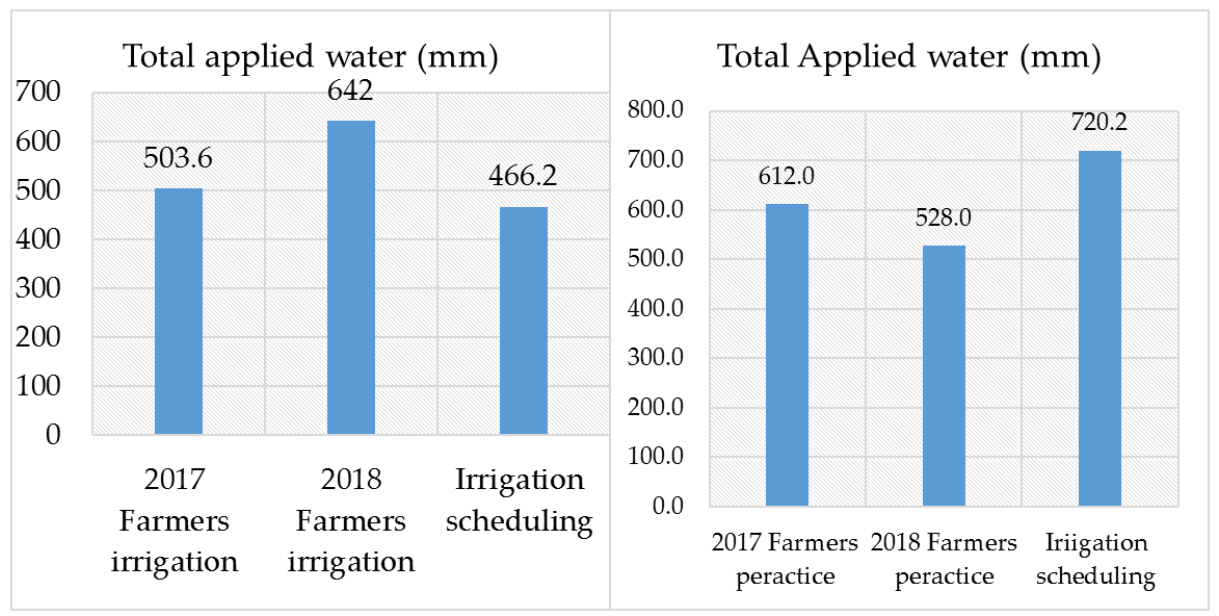

Figure 6. Direct effects of total applied water on CROPWAT irrigation scheduling versus farmers irrigation practice in 2017 and 2018 at (A) Ligaba and (B) Wobomariam site.

\subsection{Effects of CROPWAT Irrigation Scheduling on Crop Water Use Efficiency and Yield}

For Ligaba site analyzed result shows that the highest
WUE was obtained in 2017 (34 kg/ha mm, $28 \mathrm{~kg} / \mathrm{ha} \mathrm{mm})$ and in $2018(33 \mathrm{~kg} / \mathrm{ha} \mathrm{mm}, 23 \mathrm{~kg} / \mathrm{ha} \mathrm{mm})$ were CROPWAT irrigation scheduling and farmers irrigation practice respectively. Whereas, for Wobomariam site the result revealed that $(24 \mathrm{~kg} / \mathrm{ha} \mathrm{mm}, 22 \mathrm{~kg} / \mathrm{ha} \mathrm{mm})$ and in $2018(25$ 
$\mathrm{kg} / \mathrm{ha} \mathrm{mm}, 27 \mathrm{~kg} / \mathrm{ha} \mathrm{mm}$ ) were CROPWAT irrigation scheduling and farmers irrigation practice respectively (Table 9). This result improves CROPWAT8 irrigation scheduling for hot pepper WUE increasing to $43.7 \%$ and $9 \%$ for Ligaba site and Wobomariam site respectively as compared with wfarmers irrigation practice. It is commonly said that improving irrigation efficiencies is of paramount importance under water scarce situations because high efficiency would represent conditions of near-optimal use of the water. This is generally true when the idea behind is that less water should be abstracted from surface or ground waters to produce a certain yield. Nevertheless, in an area where water is fully available, it is important to consider the deep percolation and runoff loss. The results of this research are in agreement with GENÇOĞLAN and YAZAR [37], [38] who reported that
WUE values decreased with increasing irrigation level.

A one-tailed paired t-test was used to analyze the impacts of fresh hot pepper yield for CROPWAT irrigation scheduling system to farmers irrigation practice. From this the obtained result shows that there was a significant different in 2017 for both sites and in 2018 for wobomariam site. Whereas in Ligaba site non-significant in 2018 between irrigation scheduling and farmers irrigation practice (Table 9).

The mean crop yields of the fresh hot pepper were increased by $12 \%$ and $3.4 \%$ for 2017 and 2018 respectively at Ligaba site and $31.4 \%$, and $25.8 \%$ at Wobomariam site respectively under irrigation scheduling when compared with farmers irrigation practice. According to Dorji, Behboudian [20] who reports hot pepper yield affected by deficit irrigation level. So, this study shows similar yield effects.

Table 10. Effects of farmers irrigation practice and CROPWAT irrigation scheduling on hot pepper fresh yield, total applied water and water use efficiency.

Dangela Ligaba

\begin{tabular}{|c|c|c|c|c|c|c|}
\hline \multirow[b]{2}{*}{ Treatments } & \multicolumn{3}{|l|}{2017} & \multicolumn{3}{|l|}{2018} \\
\hline & $\begin{array}{l}\text { Total Fresh } \\
\text { yield (kg/ha) }\end{array}$ & $\begin{array}{l}\text { Total applied } \\
(\mathrm{mm})\end{array}$ & $\begin{array}{l}\text { WUE (kg/ha } \\
(\mathrm{mm})\end{array}$ & $\begin{array}{l}\text { Fresh yield } \\
\text { (kg/ha) }\end{array}$ & $\begin{array}{l}\text { Total applied } \\
\text { water }(\mathrm{mm})\end{array}$ & $\begin{array}{l}\text { WUE (kg/ha } \\
\mathrm{mm})\end{array}$ \\
\hline CROPWAT Irrigation scheduling & 15830 & 466 & 34 & 15360 & 466 & 33 \\
\hline Farmer's irrigation practice & 14125 & 504 & 28 & 14850 & 642 & 23 \\
\hline $\mathrm{Cv}$ & 19.09 & - & 7.5 & 6.12 & - & 12.52 \\
\hline $\operatorname{LSD}(0.05)$ & $*$ & - & $*$ & NS & - & $* *$ \\
\hline
\end{tabular}

Wobomariam

\begin{tabular}{|c|c|c|c|c|c|c|}
\hline \multirow[b]{2}{*}{ Treatments } & \multicolumn{3}{|l|}{2017} & \multicolumn{3}{|l|}{2018} \\
\hline & $\begin{array}{l}\text { Total Fresh } \\
\text { yield kg/ha }\end{array}$ & $\begin{array}{l}\text { Total applied } \\
\text { water }(\mathbf{m m})\end{array}$ & $\begin{array}{l}\text { WUE } \\
\text { (kg/ha mm) }\end{array}$ & $\begin{array}{l}\text { Fresh yield } \\
\text { (kg/ha) }\end{array}$ & $\begin{array}{l}\text { Total applied } \\
\text { water }(\mathbf{m m})\end{array}$ & $\begin{array}{l}\text { WUE (kg/ha } \\
\mathrm{mm})\end{array}$ \\
\hline Irrigation scheduling & 17300 & 720 & 24 & 17800 & 720 & 25 \\
\hline Farmer's irrigation practice & 13160 & 612 & 22 & 14150 & 528 & 27 \\
\hline $\mathrm{Cv}$ & 3.4 & - & 7.5 & 16 & - & 11.2 \\
\hline $\operatorname{LSD}(0.05)$ & $* *$ & - & $*$ & $*$ & - & $*$ \\
\hline
\end{tabular}

Note. WUE, CV, NS, * and ** are water use efficiency, coefficients of variation, non-significance difference, significance difference and highly significance difference respectively.

\subsection{Comparative Evaluations of CROPWAT Irrigation Scheduling Versus Farmers Practice on Field by Participants}

For both sites field day was implemented with farmers and stakeholders' farmers were evaluating the experiment, farmers irrigation practice versus CROPWAT irrigation scheduling. According to focus group discussions farmers feedback were thoughtful about cultivated crops for irrigation needs simple technical knowledge. This technical system was amounts of irrigation water depends on crop growth stage and when and how much irrigate is used to obtained optimum crop yield. In addition to this participant researcher and Development agriculture (DA) also evaluates simple computer programming CROPWAT irrigation scheduling system is important for locality climate conditions crop water requirements and irrigation water requirements.

\section{Conclusion and Recommendation}

This research showed the potential benefits of CROPWAT irrigation scheduling simple computer program compared to farmers irrigation practice on farm conditions under small scale irrigation system in Northwest Ethiopia. The applicability of CROPWAT irrigation scheduling system was experimentally demonstrated to estimate hot pepper irrigation water requirement with when and how much irrigating as well as growth stage. From January to May irrigation season gross irrigation depth for hot pepper considering field irrigation application efficiency of $60 \%$ was 466.4 and 720.2 for Ligaba and Wobomariam site respectively.

Water use efficiency and hot pepper fresh yield were significantly increased under the CROPWAT8 irrigation scheduling as compared with farmers irrigation practice. Hot pepper water use efficiency was improved by $43.7 \%$ and $9 \%$ and hot pepper fresh yield was improved by $12 \%$ and $31.4 \%$ for Ligaba (high land) and Wobomariam (low Land) North west Ethiopia respectively. In addition to this participant farmers and stakeholders also evaluate CROPWAT irrigation scheduling positively it could be used locality conditions. This shows the CROPWAT irrigation scheduling has increased significant benefits (proper water usage and hot pepper yield increment). We conclude that the CROPWAT 
irrigation scheduling system is a promising technology to estimate crop water and irrigation water requirements with when and how much irrigate to corresponding growth stage. And also, that can improve hot pepper fresh yield of smallscale irrigation in Northwest Ethiopia.

\section{Conflicts of Interest}

The authors declare no conflict of interest.

\section{Acknowledgements}

We would like to acknowledge the Ethiopian National Meteorological Agency (ENMA) for providing quality data and Pawe Agricultural research center soil laboratory soil analysis data for this research. In addition to this we would like to thanks Mr. Belete Wondiferaw and Mr. Jemal Yimer the contributions of this research for quality data collectors.

\section{References}

[1] MoFED, E., Ethiopia: Building on progress a plan for accelerated and sustained development to end poverty (pasdep), 2006, Addis Ababa: The Federal Democratic Republic of Ethiopia Ministry of Finance ....

[2] Makombe, G., D. Kelemework, and D. Aredo, A comparative analysis of rainfed and irrigated agricultural production in Ethiopia. Irrigation and Drainage Systems, 2007. 21 (1): p. 35-44.

[3] Ewonetu, G., Identifing Major Constraints of Ground Water Use for Irrigated Crop Production: Fogera Plain, North Western Ethiopia, 2012, Cornell University.

[4] Beshir, S., Review on estimation of crop water requirement, irrigation frequency and water use efficiency of cabbage production. Journal of Geoscience and Environment Protection, 2017.5 (07): p. 59.

[5] Stevens, J. B., Adoption of irrigatio scheduling methods in South Africa, 2007, University of Pretoria.

[6] Nikolaou, G., et al., Implementing sustainable irrigation in water-scarce regions under the impact of climate change. Agronomy, 2020. 10 (8): p. 1120.

[7] Raine, S., et al., Soil-water and solute movement under precision irrigation: knowledge gaps for managing sustainable root zones. Irrigation Science, 2007. 26 (1): p. 91-100.

[8] Smith, M., CROPWAT: A computer program for irrigation planning and management. 1992: Food \& Agriculture Org.

[9] Simonne, E., M. Dukes, and D. Haman, Principles and practices of irrigation management for vegetables. EDIS, 2006. 2006 (3).

[10] Howell, T. Irrigation scheduling research and its impact on water use. in Evapotranspiration and irrigation scheduling, Proceedings of the international conference. 1996. American Society of Agricultural Engineer St. Joseph, MI.

[11] Kharrou, M. H., et al., Water use efficiency and yield of winter wheat under different irrigation regimes in a semi-arid region. Agricultural Sciences in China, 2011. 2 (03): p. 273-282.
[12] Evans, R. G. and E. J. Sadler, Methods and technologies to improve efficiency of water use. Water resources research, 2008. 44 (7).

[13] Ismail, S. M. and K. Ozawa. Effect of irrigation interval on growth characteristics, plant water stress tolerance and water use efficiency for Chile pepper. in Thirteenth International Water Technology Conference, IWTC. 2009.

[14] Jones, H. Irrigation scheduling-comparison of soil, plant and atmosphere monitoring approaches. in $\mathrm{V}$ International Symposium on Irrigation of Horticultural Crops 792. 2006.

[15] Strelkoff, T., et al., Surface-irrigation evaluation models: Application to level basins in Egypt. Transactions of the ASAE, 1999. 42 (4): p. 1027.

[16] Allen, R. G., et al., Crop evapotranspiration-Guidelines for computing crop water requirements-FAO Irrigation and drainage paper 56. Fao, Rome, 1998. 300 (9): p. D05109.

[17] Zayzay Jr, J. B., Validation of the fao aquacrop model for irrigated hot pepper (capsicum frustescensvarlegon 18) in the coastal savannah ecological zone of Ghana, 2015, University of Cape Coast.

[18] Sayyari, M. and F. Ghanbari, Effects of super absorbent polymer A200 on the growth, yield and some physiological responses in sweet pepper (Capsicum annuum L.) under various irrigation regimes. International Journal of Agricultural and Food Research, 2012. 1 (1).

[19] Antonious, G. F., J. E. Meyer, and J. C. Snyder, Toxicity and repellency of hot pepper extracts to spider mite, Tetranychus urticae Koch. Journal of Environmental Science and Health, Part B, 2006. 41 (8): p. 1383-1391.

[20] Dorji, K., M. Behboudian, and J. Zegbe-Dominguez, Water relations, growth, yield, and fruit quality of hot pepper under deficit irrigation and partial rootzone drying. Scientia Horticulturae, 2005. 104 (2): p. 137-149.

[21] Saaty, T. L., Relative measurement and its generalization in decision making why pairwise comparisons are central in mathematics for the measurement of intangible factors the analytic hierarchy/network process. RACSAM-Revista de la Real Academia de Ciencias Exactas, Fisicas y Naturales. Serie A. Matematicas, 2008. 102 (2): p. 251-318.

[22] De Winter, J. C., Using the Student's t-test with extremely small sample sizes. Practical Assessment, Research, and Evaluation, 2013. 18 (1): p. 10.

[23] Yimam, A. Y., et al., Experimental evaluation for the impacts of conservation agriculture with drip irrigation on crop coefficient and soil properties in the sub-humid Ethiopian highlands. Water, 2020. 12 (4): p. 947.

[24] Belay, S. A., et al., The Response of Water and Nutrient Dynamics and of Crop Yield to Cona servation Agriculture in the Ethiopian Highlands. Sustainability, 2020. 12 (15): p. 5989.

[25] Assefa, T., et al., Experimental Evaluation of Conservation Agriculture with Drip Irrigation for Water Productivity in SubSaharan Africa. Water, 2019. 11 (3): p. 530.

[26] Zotarelli, L., et al., Step by step calculation of the PenmanMonteith Evapotranspiration (FAO-56 Method). Institute of Food and Agricultural Sciences. University of Florida, 2010. 
[27] Bos, M. G., et al., Water requirements for irrigation and the environment. 2008: Springer Science \& Business Media.

[28] Doorenbos, J. and W. Pruitt, Crop water requirements. FAO Irrigation and drainage paper No. 24. FAO, Rome, 1977: p. 34-37.

[29] Savva, A. P. and K. Frenken, Crop water requirements and irrigation scheduling. Irrigation manual module 4. Water Resources Development and Management Officers, FAO, Sub-Regional Office for East and Southern Africa, 2002.

[30] Markos, D. and S. Mekonen, Effects of Inter and Intra Row Spacing on Growth and Yield Components of Hot Pepper.

[31] Salau, A. W., et al., Growth and fruit yield of pepper species as affected by plant spacing. International Journal of Vegetable Science, 2019. 25 (2): p. 164-175.

[32] Ewaid, S. H., S. A. Abed, and N. Al-Ansari, Crop water requirements and irrigation schedules for some major crops in Southern Iraq. Water, 2019. 11 (4): p. 756.

[33] Alemayehu, Y., J. M. Steyn, and J. G. Annandale, FAO-type crop factor determination for irrigation scheduling of hot pepper (Capsicum annuum L.) cultivars. South African Journal of Plant and Soil, 2009. 26 (3): p. 186-194.

[34] Mamo, A., Technical and Economical Feasibility of Small Holder Drip Irrigation using Harvested Rainwater for Onion Production at Dire Dawa, 2005, MSc. Thesis, Alamaya University, Ethiopia.

[35] Savva, A. P. and K. Frenken, Crop water requirements and irrigation scheduling. 2002: FAO Sub-Regional Office for East and Southern Africa Harare.

[36] Hargreaves, G. L., G. H. Hargreaves, and J. P. Riley, Irrigation water requirements for Senegal River basin. Journal of Irrigation and Drainage Engineering, 1985. 111 (3): p. 265275 .

[37] GENÇOĞLAN, C. and A. YAZAR, The effects of deficit irrigations on corn yield and water use efficiency. Turkish Journal of Agriculture and Forestry, 1999. 23 (2): p. 233-242.

[38] Erdem, Y., et al., Irrigation scheduling for watermelon with crop water stress index (CWSI). Journal of Central European Agriculture, 2005. 6 (4): p. 449-460. 